\title{
PENINGKATAN KUALITAS PEMBELAJARAN IPA PADA MATERI SISTEM PENCERNAAN MANUSIA DENGAN STRATEGI JIGSAW-LESSON STUDY PADA SISWA KELAS VIII-A SMP NEGERI 3 PACITAN
}

\author{
Edi Winarno \\ SMP Negeri 3 Pacitan \\ ediwinar@gmail.com
}

\begin{abstract}
This study aims to improve the quality of science learning outcomes matter of human digestive system in class VIII-A of SMP Negeri 3 Pacitan school year 2011/2012 through the implementation of learning strategy Jigsaw - Lesson study. The results show that the quality of the science learning process increases. It can be seen from the increase in the percentage of success of the action on the first cycle of $62.59 \%$ increased by $7.41 \%$ after the second cycle, which becomes $80.00 \%$ and based on the level of success include the category very well. In addition it also increases the percentage of mastery learning in the time before the actions of $38.89 \%$, after the first cycle of $72.22 \%$ and the second cycle in the classical mastery learning students reach $100 \%$. The average value of learning outcomes also increased, at the time before the action was 71.00 , after the first cycle of 72.31 and the second cycle in the classical mastery learning students achieve 76.31. From the results of this study concluded that learning with LS - Jigsaw strategy can improve the quality of science teaching, the students of class VIII - A of SMP Negeri 3 Pacitan school year 2011/2012 .
\end{abstract}

Keyword: learning, jigsaw, lesson study

\section{PENDAHULUAN}

Pelaksanaan pembelajaran IPA di SMPN 3 Pacitan khususnya pada kelas VIII-A cenderung "text book oriented" dan "teacher oriented". Siswa kurang terlibat pada kegiatan pembelajaran, siswa takut untuk bertanya dan mengeluarkan pendapat, siswa kurang bisa bekerja sama dengan kelompok, siswa kurang menghargai siswa lain sehingga dari segi kualitas bisa dikatakan bahwa proses pembelajaran IPA di SMP Negeri 3 Pacitan masih rendah. Kualitas proses pembelajaran IPA yang rendah berakibat pada hasil belajar siswa yang rendah. Hasil belajar siswa kelas VIII-A SMP Negeri 3 Pacitan yang rendah tersebut terlihat dari sebagian besar siswa masih mengikuti remidi karena nilai yang diperoleh belum memenuhi Kriteria Ketuntasan Minimal (KKM) mata pelajaran IPA yang ditetapkan di SMP Negeri 3 Pacitan yaitu $73 \%$.

Kualitas proses pembelajaran IPA dapat dilihat dari segala tingkah laku atau kegiatan belajar siswa yang menerapakan indikator dari lima elemen pembelajaran kooperatif. Lima elemen pembelajaran kooperatif tersebut menurut Roger dan Davidson dalam Lie (2002) meliputi saling ketergantungan positif (positive interdependence), akuntabilitas individual (individual accountability), interaksi tatap muka (face to face interaction), keterampilan menjalin hubungan antar anggota kelompok (interpersonal and small group skill) dan proses kelompok (group-processing).

Hasil belajar sesuai dengan tujuantujuan pendidikan menurut Arikunto (2008) dapat dikelompokkan menjadi 3 ranah, yaitu ranah kognitif, ranah afektif dan ranah psikomotor. Krathwol (2002) mengklasifikasikan ranah kognitif menjadi 6 tingkatan yaitu remember (mengingat), Understand (memahami), Apply (aplikasi), Analyze (analisis), Evaluate (evaluasi) dan Create (mencipta).

Jigsaw merupakan salah satu bentuk strategi pembelajaran kooperatif. Menurut 
Johnson and Johnson (1999) dalam Chan (2004) pembelajaran kooperatif learning adalah instruksional praktis dimana siswa saling membantu untuk belajar di sebuah kelompok kecil untuk mencapai tujuan tertentu. Subadi (2010), berpendapat jigsaw adalah suatu pendekatan kooperatif yang setiap timnya beranggotakan 4-6 siswa yang akan mempelajari bahan pembelajaran yang telah dibagi atas enam bagian, satu bagian untuk satu anggota.

Tahap-tahap dalam penyelenggaraan jigsaw adalah (1) Siswa dikelompokkan dalam bentuk kelompok kecil. Pembentukan kelompok siswa tersebut dapat dilakukan oleh guru berdasarkan pertimbangan tertentu. (2) Pembentukan kelompok ahli. Siswa dikelompokkan menjadi beberapa kelompok disesuaikan dengan banyaknya materi yang akan didiskusikan. (3) Siswa dari kelompok ahli kembali ke kelompok asal. Setelah masingmasing perwakilan tersebut menguasai materi yang ditugaskannya, mereka kembali ke kelompok masing-masing atau kelompok asalnya. (4) Pemberian tes kepada siswa. Siswa diberi tes/kuis oleh guru, hal tersebut dilakukan untuk mengetahui pemahaman materi oleh siswa. Susilo (2009) salah satu strategi pembelajaran yang digunakan pada Penelitian Tindakan Kelas yang dirancang dengan lesson study adalah strategi pembelajaran jigsaw.

Berdasarkan jawaban siswa yang diperoleh melalui kuisioner, peneliti menyimpulkan bahwa lesson study dan PTK dapat dikombinasikan dan menjadi cara yang sangat baik untuk meningkatkan profesionalitas guru. Lesson study dan PTK mirip karena keduanya membutuhkan observer dan memiliki fase perencanaan, pelaksanaan dan refleksi. Berdasarkan opini siswa pada penelitian tersebut, melalui lesson study guru dapat menemukan kesulitan siswa dan melalui refleksi terhadap pembelajaran yang telah dilakukan, guru juga dapat mengetahui bagaimana cara untuk menolong siswa mengatasi kesulitan belajar. Chassels (2009) bahwa keuntungan pelaksanaan lesson study adalah dapat membiasakan budaya kolaborasi profesional di sekolah yang dapat menghasilkan peningkatan yang berkelanjutan pada proses belajar mengajar. Hal tersebut dibutuhkan dalam dunia dengan perubahan yang sangat cepat pada abad 21 ini.

Hipotesis tindakan dalam penelitian ini yaitu "Kualitas pembelajaran IPA materi sistem pencernaan makanan manusia pada siswa kelas VIII-A SMP Negeri 3 Pacitan dapat ditingkatkan melalui penerapan strategi jigsaw-lesson study".

\section{METODE}

Penelitian ini merupakan Penelitian Tindakan Kelas (PTK). Penelitian Tindakan Kelas adalah penelitian reflektif yang bersiklus (berdaur), yang dilakukan oleh guru dalam rangka memperbaiki kualitas pembelajaran. Penelitian ini tergolong penelitian tindakan dengan dua siklus. Masing-masing siklus terdiri atas tahapan yang sesuai dengan tahapan pelaksanaan lesson study yaitu perencanaan (plan), pelaksanaan $(d o)$ dan refleksi (see).

Subyek penelitian adalah peneliti sebagai guru model, tim matapelajaran sebagai observer dan objek penelitian adalah siswa kelas VIII-A SMP Negeri 3 Pacitan yang berjumlah 36 siswa terdiri atas 17 siswa laki-laki dan 19 siswa perempuan.

Data dalam penelitan ini dikelompokkan menjadi dua yaitu data kualitas proses pembelajaran IPA dan data hasil pembelajaran IPA.

Teknik pengambilan data meliputi:

1. Kualitas proses pembelajaran

$\%$ aktifitas kelompok : $\underline{\boldsymbol{\Sigma}}$ skor kelompok x $100 \%$ $\boldsymbol{\Sigma}$ skor maks. kelompok

2. Keberhasilan tindakan secara klasikal

$\%$ keberhasilan tindakan : $\underline{\boldsymbol{\Sigma}}$ skor klasikal x $100 \%$ $\boldsymbol{\Sigma}$ skor klasikal maks. 
Tabel 1. Kriteria Keberhasilan Tindakan Proses Pembelajaran IPA

\begin{tabular}{clcc}
$\begin{array}{c}\% \\
\text { Keberha- } \\
\text { silan } \\
\text { Tindakan }\end{array}$ & $\begin{array}{c}\text { Taraf } \\
\text { Keberhasilan }\end{array}$ & $\begin{array}{c}\text { Nilai } \\
\text { Huruf }\end{array}$ & $\begin{array}{c}\text { Nilai } \\
\text { Angka }\end{array}$ \\
\hline $80-100 \%$ & Sangat baik & A & 5 \\
$60-79 \%$ & Baik & B & 4 \\
$40-59 \%$ & Cukup & C & 3 \\
$10-39 \%$ & Kurang & D & 2 \\
$0-9 \%$ & Sangat & E & 1 \\
& kurang & & \\
\hline
\end{tabular}

Analisis data mengenai hasil pembelajaran IPA berupa hasil belajar kognitif siswa yang diperoleh dari tes tertulis dan dinilai berdasarkan Rubrik Penilaian Tes Hasil Belajar Kognitif Siswa adalah dengan cara membandingkan skor hasil belajar masing-masing siswa dengan kriteria ketuntasan minimum (KKM) di SMP Negeri 3 Pacitan yaitu 73. Tindakan dianggap berhasil jika ketuntasan klasikal mencapai $85 \%$. Ketuntasan klasikal dihitung dengan rumus sebagai berikut.

\% Ketuntasan klasikal : $\boldsymbol{\Sigma}$ Siswa skor $\mathscr{K K M} \times 100 \%$ $\boldsymbol{\Sigma}$ Siswa dalam kelas

\section{HASIL DAN PEMBAHASAN}

\section{Pra Siklus}

\section{Observasi Awal}

Observasi awal peneliti melakukan wawancara dengan guru mata pelajaran IPA SMP kelas VIII dan juga beberapa orang siswa. Peneliti juga melakukan pengamatan langsung pada saat kegiatan pembelajaran. Temuan pada observasi awal disimpulkan bahwa permasalahan yang terjadi di SMP Negeri 3 Pacitan adalah pemberian pengalaman belajar yang belum bisa mengaktifkan siswa. Sebelum dilakukan tindakan, dilakukan tahap persiapan yang sesuai dengan salah satu tahapan dalam pelaksanaan lesson study yaitu tahap plan atau perencanaan.

Hasil temuan diatas, diketahui bahwa kurang maksimalnya konsentrasi siswa dalam pembelajaran IPA disebabkan oleh beberapa permaslahanan yaitu, kecenderungan guru masih bekerja secara individual, pemanfaat strategi pembelajaran yang tidak sesuai dan cenderung ceramah diiktuti seringnya guru tidak menyampaikan tujuan pembelajaran yang akan dilaksanaakan saat itu, pengelolaan kelas yang monoton yaitu klasikal dengan rendahnya keterlibatan siswa dalam proses pembelajaran, dan penilaian yang dipaksakan hanya melalui tes saja.

\section{Siklus I}

Siklus I ini dilakukan tindakan sesuai dengan lesson study, yang terdiri dari tiga tahapan yaitu tahap plan, do dan tahap see. Tahap plan atau perencaanaan, dilakukan sejumlah kegiatan perencanaan dan menghasilkan perangkat pembelajaran berupa: (1) rencana pelaksanaan pembelajaran 1 yang menerapkan strategi jigsaw, (2) instrumen penilaian kualitas proses pembelajaran IPA berupa rubrik penilaian aktivitas kooperatif siswa dan (3) instrumen penilaian hasil belajar siswa berupa soal tes hasil belajar kognitif siswa 1. Pada tahap do atau pelaksanaan, dilakukan kegiatan pembelajaran dengan menerapka strategi jigsaw dengan hasil sebagai berikut. Berdasarkan data yang diperoleh mengenai kualitas proses pembelajaran IPA pada siklus I yang dilihat dari segala tingkah laku atau kegiatan belajar siswa yang menerapakan indikator dari lima elemen pembelajaran kooperatif, diketahui bahwa kelompok 1 memiliki persentase aktivitas kooperatif kelompok sebesar $68,89 \%$, kelompok 2 sebesar 55,56\%, kelompok 3 mendapatkan skor tertinggi dengan persentase $84,44 \%$, kelompok 4 sebesar $62,22 \%$, kelompok 5 sebesar 51,11\% dan kelompok 6 sebesar $53,33 \%$. Persentase keberhasilan tindakan secara klasikal yaitu $62,59 \%$. Jika dibandingkan dengan kriteria keberhasilan tindakan pada kualitas proses pembelajaran IPA seperti yang tertera pada Tabel 3.1 maka keberhasilan tindakan secara klasikal tersebut tergolong baik.

Berdasarkan data yang diperoleh mengenai kualitas hasil pembelajaran IPA pada siklus I, nilai rata-rata siswa 
mengalami peningkatan dari nilai yang diperoleh pada saat sebelum perlakuan/awal yaitu dari 71 naik menjadi 72 atau naik sebesar 1 , setelah siklus I. Selain itu kenaikan juga terjadi pada persentase jumlah siswa yang mencapai atau melampui KKM pada saat sebelum perlakuan/awal yaitu dari $38,89 \%$ naik menjadi $75 \%$ atau naik sebesar $36,11 \%$ setelah siklus I.

Rekomendasi pelaksanaan strategi pembelajaran jigsaw-lesson study berdasarkan pelaksanaan siklus I adalah 1) Guru perlu lebih terampil dalam memotivasi siswa, salah satunya dengan cara mengajak siswa untuk terlibat langsung dalam setiap kegiatan yang akan dilakukan dan lebih jelas dalam menyampaikan tujuan serta langkahlangkah pembelajaran. 2) Guru perlu mengalokasikan waktu untuk setiap langkah-langkah pembelajaran secara baik dan tegas untuk menyuruh siswa menghentikan kegiatan yang dilakukannya dalam suatu langkah pembelajaran jika waktu yang dialokasikan untuk kegiatan tersebut telah habis.

\section{Siklus II}

Mengacu pada hasil refleksi dan rekomendasi siklus I, baik mengenai keberhasilam maupun kegagalan yang terjadi, maka pada tahap plan atau perencaanaan dibuat rencana tindakan untuk siklus II sebagai tindak lanjut dari rekomendasi siklus I. Pada tahap do atau pelaksanaan, dilakukan kegiatan pembelajaran dengan menerapka strategi jigswa dengan hasil sebagai berikut.

Siklus II, persentase aktivitas kooperatif masing-masing kelompok ratarata meningkat jika dibandingkan siklus I kecuali untuk kelompok. Kelompok 1 memiliki persentase aktivitas kooperatif kelompok sebesar $71,11 \%$, kelompok 2 sebesar $82,22 \%$, kelompok 3 mendapatkan skor tertinggi dengan persentase $95,56 \%$, kelompok 4 sebesar $68,89 \%$, kelompok 5 sebesar 71,11\% dan kelompok 6 sebesar $91,11 \%$. Jika dibandingkan dengan kriteria keberhasilan tindakan pada kualitas proses pembelajaran IPA seperti yang tertera pada Tabel 3.1 maka keberhasilan tindakan secara klasikal pada siklus II mengalami peningkatan dari siklus I yaitu menjadi tergolong sangat baik. Begitu juga persentasenya sudah mengalami peningkatan yaitu $80,00 \%$. Peningkatan persentase aktivitas kooperatif kelompok dan keberhasilan tindakan secara klasikal menunjukkan adanya peningkatan kualitas proses pembelajaran IPA di kelas VIII-A SMP Negeri 3 Pacitan dari tindakan yang dilakukan pada siklus I dan siklus II.

Berdasarkan data mengenai hasil pembelajaran IPA berupa hasil belajar kognitif siswa yang diperoleh dari tes tertulis dan dinilai berdasarkan Rubrik Penilaian Tes Hasil Belajar Kognitif Siswa pada siklus I, diketahui bahwa persentase ketuntasan klasikal hanya mencapai $75 \%$ sedangkan pada siklus II persentase ketuntasan klasikal meningkat menjadi 100\%. Sehingga keberhasilan tindakan dapat mencapai ketuntasan klasikal yaitu $100 \%$ atau naik sebesar $25 \%$ dari siklus I. Dicapainya target ketuntasan belajar secara klasikal mununjukan bahwa dalam proses pembelajaran baik siklus I maupun siklus II, siswa benar-benar menguasai konsep yang dipelajari di kelompok ahli maupun konsep yang diperoleh dari anggota kelompok lain di kelompok asal.

Hasil refleksi atau see diketahui bahwa pelaksanaan pembelajaran pada siklus II sudah sesuai dengan RPP dan durasi masing-masing kegiatan sudah sesuai. Siswa terlihat bersemangat dalam mengikuti pembelajaran dan penguasaan konsep siswa terhadap materi yang dipelajari lebih baik daripada siklus I. Hal tersebut dimungkinkan karena kerjasama dan tanggungjawab siswa terlihat lebih baik daripada pembelajaran siklus I.

Guru model berpendapat bahwa pelaksanaan pembelajaran dengan strategi jigsaw-lesson study pada siklus II lebih baik daripada siklus I karena siswa lebih mengerti dengan langkah-langkah pembelajaran yang akan dilakukan. Hal lain yang terlihat meningkat dari 
pelaksanaan pembelajaran siklus I adalah konsep yang diperoleh siswa di kelompok ahli dapat disampaikan dengan lebih baik ke anggota kelompok asal. Pendapat tersebut didukung oleh data pengamatan aktivitas siswa yang diambil oleh observer.

Berdasarkan hasil refleksi, diketahui pula bahwa secara keseluruhan, penerapan strategi jigsaw-lesson study pada siklus I dan II dapat menghasilkan rancangan pembelajaran yang lebih baik dan refleksi pembelajaran yang lebih detail sehingga berguna untuk memperbaiki proses pembelajaran.

Berdasarkan analisis data kualitas proses dan hasil pembelajaran IPA kelas VIII-A SMP Negeri 3 Pacitan tahun ajaran 2011/2012 pada Kompetensi Dasar 1.4 Mendeskripsikan sistem pencernaan pada manusia dan hubungannya dengan kesehatan yang menerapkan strategi jigsaw-lesson study, diketahui bahwa terjadi peningkatan persentase keberhasilan tindakan secara klasikal dari siklus I dan siklus II yaitu $62,59 \%$ menjadi $80,00 \%$ dengan kriteria sangat baik.

Peningkatan kualitas proses pembelajaran IPA yang dilihat dari tingkah laku atau kegiatan belajar siswa yang menerapakan indikator dari lima elemen pembelajaran kooperatif meliputi saling ketergantungan positif, akuntabilitas individual, interaksi tatap muka, keterampilan menjalin hubungan antar anggota kelompok dan proses kelompok dari siswa.

Penerapan strategi jigsaw-lesson study diasumsikan memperkuat kelebihan masing-masing elemen. Hal ini dapat terjadi karena dengan lesson study, guru melakukan kolaborasi dengan guru lain untuk merancang, mengamati dan melakukan refleksi terhadap pembelajaran yang dilakukan. Uraian di atas menegaskan bahwa penerapan strategi jigsaw-lesson study berpengaruh terhadap peningkatan kualitas proses pembelajaran seperti yang ditunjukkan oleh hasil observasi terhadap aktivitas kooperatif siswa kelas VIII-A SMP Negeri 3 Pacitan. Peningkatan kualitas proses pembelajaran IPA tersebut diikuti dengan peningkatan hasil belajar IPA VIII-A SMP Negeri 3 Pacitan.

Peningkatan hasil belajar IPA dilihat dari peningkatan persentase ketuntasan klasikal. Sebelum tindakan persentase ketuntasan klasikal hanya mencapai 38,89\%. Pada siklus I, persentase ketuntasan klasikal meningkat mencapai $75 \%$ sedangkan pada siklus II persentase ketuntasan klasikal telah menjadi $100 \%$. Peningkatan ini diasumsikan merupakan pengaruh dari penerapan strategi jigsawlesson study.

\section{SIMPULAN}

Penerapan strategi jigsaw-lesson study dapat meningkatkan kualitas proses pembelajaran dan hasil pembelajaran siswa pada materi sistem pencernaan manusia pada kelas VIII-A SMP Negeri 3 Pacitan tahun ajaran 2011/2012.

\section{DAFTAR PUSTAKA}

Lie, A. 2007. Cooperative Learning. Jakarta : Grasindo.

Arikunto, S. 2008. Dasar-Dasar Evaluasi Pendidikan. Jakarta: Bumi Aksara.

Chan and Kam-wing. 2004. Using Jigsaw II in Teacher Education Programmes. Hong Kong Teachers' Centre Journal Vol. 3

Krathwohl and David. 2002. A Revision of Bloom's Taxonomy: An Overview. Theory Into Practice, 4 (41), 212:218

Subadi, T. 2010. Lesson study Berbasis PTK. Surakarta: BP-FKIP UMS 